\title{
Demonetization: A Case in Indian Perspective
}

\author{
Anindita Adhikary, Bedanta Bora* \\ Department of Management Studies, Sikkim Manipal Institute of Technology, Sikkim, India
}

\section{Email address:}

anindita111@yahoo.com (A. Adhikary), bedanta1@yahoo.com (B. Bora)

*Corresponding author

\section{To cite this article:}

Anindita Adhikary, Bedanta Bora. Demonetization: A Case in Indian Perspective. International Journal of Economic Behavior and Organization. Vol. 5, No. 3, 2017, pp. 80-86. doi: 10.11648/j.ijebo.20170503.12

Received: June 1, 2017; Accepted: August 1, 2017; Published: August 17, 2017

\begin{abstract}
November $8^{\text {th }}, 2016$, the Government of India declared that the five hundred and one thousand rupee notes will no longer be legal tender effecting from midnight. The Reserve Bank of India (The Central Bank of the country) issued new five hundred rupee notes and two thousand rupee notes from $10^{\text {th }}$ November, 2016. This demonetization measure has been adopted in an effort to address the move against corruption, black money, terror financing and counterfeit cuurency. This move is expected to cleanse a formal economic system and improve the same. The demonetization has a significant impact on current state of the Indian economy. Thus, it is imperative to assess its short term and long term impacts. As such, in this study, an effort has been made to determine the impact of demonetization on the common men. The work is exploratory in nature and secondary data have been utilized for the purpose of analysis. The demonetization drive has affected the common public to some extent, but for larger interest of the country, such decisions were inevitable. Further, there are a few inherent benefits of this measure as well which will be reflected in long run.
\end{abstract}

Keywords: Demonetization, Money Supply, Electronic Currency, Formal Economic System

\section{Introduction}

Demonetization is a mechanism by which the government declares to withdraw from circulation the currency that is presently a legal tender and replace it with a new currency. It is a procedure by which a series of currency will cease to be a legal tender. It happens whenever there is an alteration of national currency. There could be many causes of demonetization in any economy, but the major aim of demonetization in India is to induce it a cashless economy. [1] [2]

The present Bharatiya Janata Party (BJP) government led by Mr. Narendra Modi has executed a major revolution with profound implications in the Indian economy by demonetizing the high value currency denominations of five hundred rupee notes and one thousand rupee notes and gradual replacement with new five hundred rupee and two thousand rupee denominations. [3] [4] The movement by the regime on the $8^{\text {th }}$ of November 2016 has taken the entire country by surprise. The annual report of Reserve Bank of India (RBI) as on $31^{\text {st }}$ March 2016 stated that total bank notes in circulation valued to Indian Rupee (INR) 16.42 trillion (US $\$ 240$ billion). The total worth of the old denominations in the circulation amount to INR 14.2 trillion (US \$ 210 billion), which is approximately $86 \%$ of the total value of legal tender in circulation. [2] With immediate effect the present circulation of the old denomination ceases to be the legal tender. The government announced this remarkable action to control the escalating price rise, to address the menace against corruption, terror financing, counterfeit currency and to tackle the threat of black money accumulated by income that has not been declared to the tax authorities. This step is an attempt to curb the formal economic system by making a cashless society and creating a digital India. [2]

India's demonetization exercise is quite distinct from the global economic record, in that its joint confidentiality and unexpectedness amidst normal economic and political conditions. Demonetization in other nations has occurred in the context of hyperinflation, wars, political turmoil, or other extreme circumstances. [3]

Some countries, in the past, had embraced the act of demonetization where public refused to accept the decision resulting in a big breakdown in government who implemented in their rule. In 2010, dictator of North Korea, Kim Jong-2 demonetized old currency to crack down black market, fight 
inflation and to improve the economy of the country. But this move of Kim Jong didn't give any better effect to the economic system. However, price of necessity goods increased and this led to public panic. On January 1991, Mikhail Gorbachev, the first president of the Soviet Union Government, withdrew the currency note of Ruble 50 and 100 to address black money in the country and increase the currency value. The government expected that it will lessen the market of black money and give a proper life to ordinary people. But this selection of the government considered a wrong twist and people started doubting on government that resulted in deprivation of public confidence, hyperinflation, cash drying up and even loss of businesses. Gorbachev faced a rebellion within eight months in August 1991 as the move was not a success. [5] In 1987, Myanmar's Military government demonetized 25, 35, and 75-kyat notes which represented around $80 \%$ value of money. The move was to curb black market and corruption. The decision of the government led to economic disturbance which in turn led to mass objection that killed many people. In 1984, during the military government of Muhammadu Buhari, Nigeria adopted the move of demonetization. New currency notes were introduced and banned the old notes so that old notes would be turned into unusable. However, the debt-ridden and inflation hit economy did not take the change well and the economy collapsed. In 1982, the government of Ghana demonetized currency notes of Cedi 50 to reduce tax evasion, curb corruption and manage liquidity in the country. The motion failed with the public losing trust in the banking system and changing over to physical assets and foreign currency. [5] [6]

India's demonetization exercise is not unprecedented in its own economic history. It has experienced such instances of demonetization measures twice in the past, in January 1946 and January 1978. In 1946, currency denominations of 1000 and 10,000 rupees were eliminated and fresh denominations of 1000,5000 and 10,000 rupees were initiated in 1954. The then Janata Party coalition government headed by Morarji Desai had again demonetized notes of 1000, 5000 and 10,000 rupees on January 1978 as a means to control counterfeit and black money. [7] Still, the substantial distinction is in the quantum. The earlier demonetization affected the high value denominations that made a nominal piece of currency in circulation. It can be estimated by comparing the denomination of the currency with the annual per capita Gross Domestic Product (GDP). In 1978 per capita GDP was INR 1,722 whereas currently it is INR 103,000. In 1978, currency worth INR 1.46 billion was demonetized which is just $1.7 \%$ of total notes in circulation. The value of demonetization was very small which is only $0.1 \%$ of GDP, whereas the 2016 demonetization measure is $11 \%$ of GDP.[8] Figure 1 depicts the Currency in Circulation and High Denomination Notes as $\%$ of GDP. India's currency to GDP ratio picked up the pace during the expansion period of the 2000s. This ratio turned down during the phase of high inflation in the late 2000s and early 2010s. However, the ratio recovered after 2014-15 to $12 \%$ when inflation declined. The value of high denomination notes of INR 500 and INR 1000 relative to GDP has also improved in line with rising living standards. [3] This is because the banks had been dispensing INR 500 and INR 1,000 notes owing to the logistical concerns associated with INR 100. Moreover, high inflation, especially in food items forced people to use higher denominations. [18] Further, figure 2 represents Growth in Average Currency with Public since 1954. There was no major effect on cash in 1978 as depicted in the figure. However, the recent demonetization had great, although temporary, money consequences. For 2016-17, this change is only $1.2 \%$ year-on-year, more than $2 \%$ points lesser than four earlier troughs, which averaged about 3.3\%. [3]

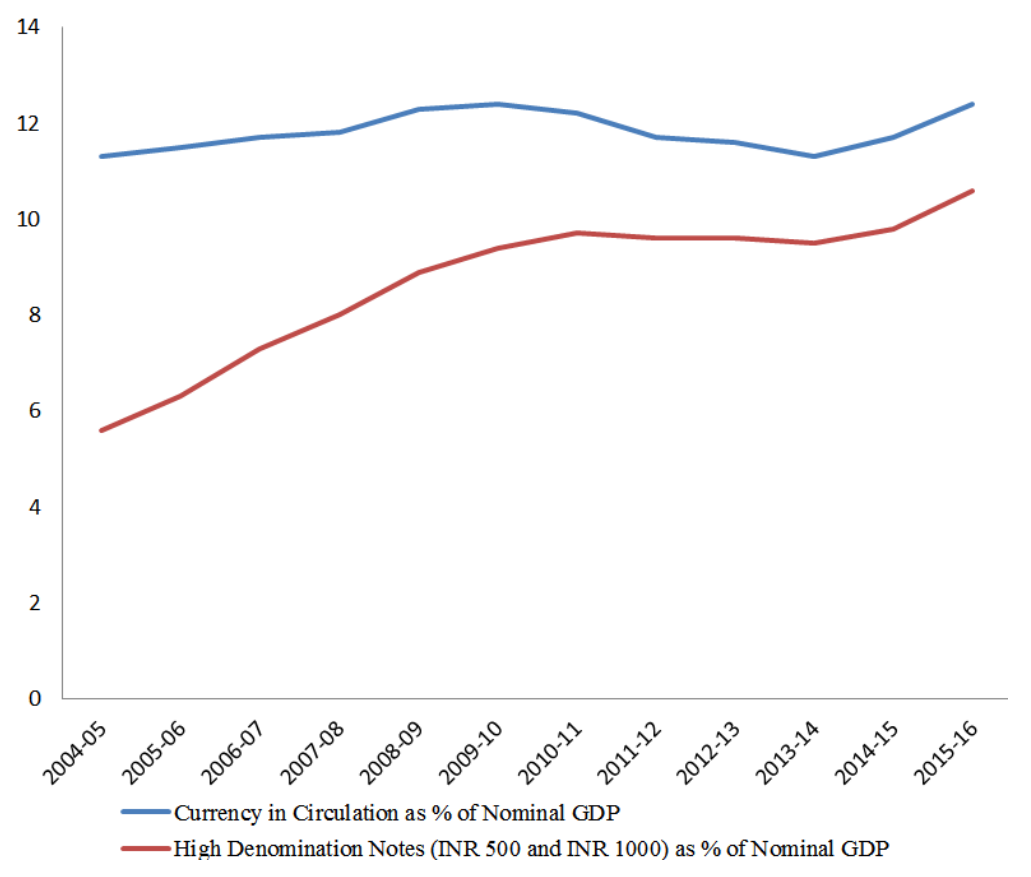

Source: RBI

Figure 1. Currency in Circulation and High Denomination Notes as\% of GDP. 


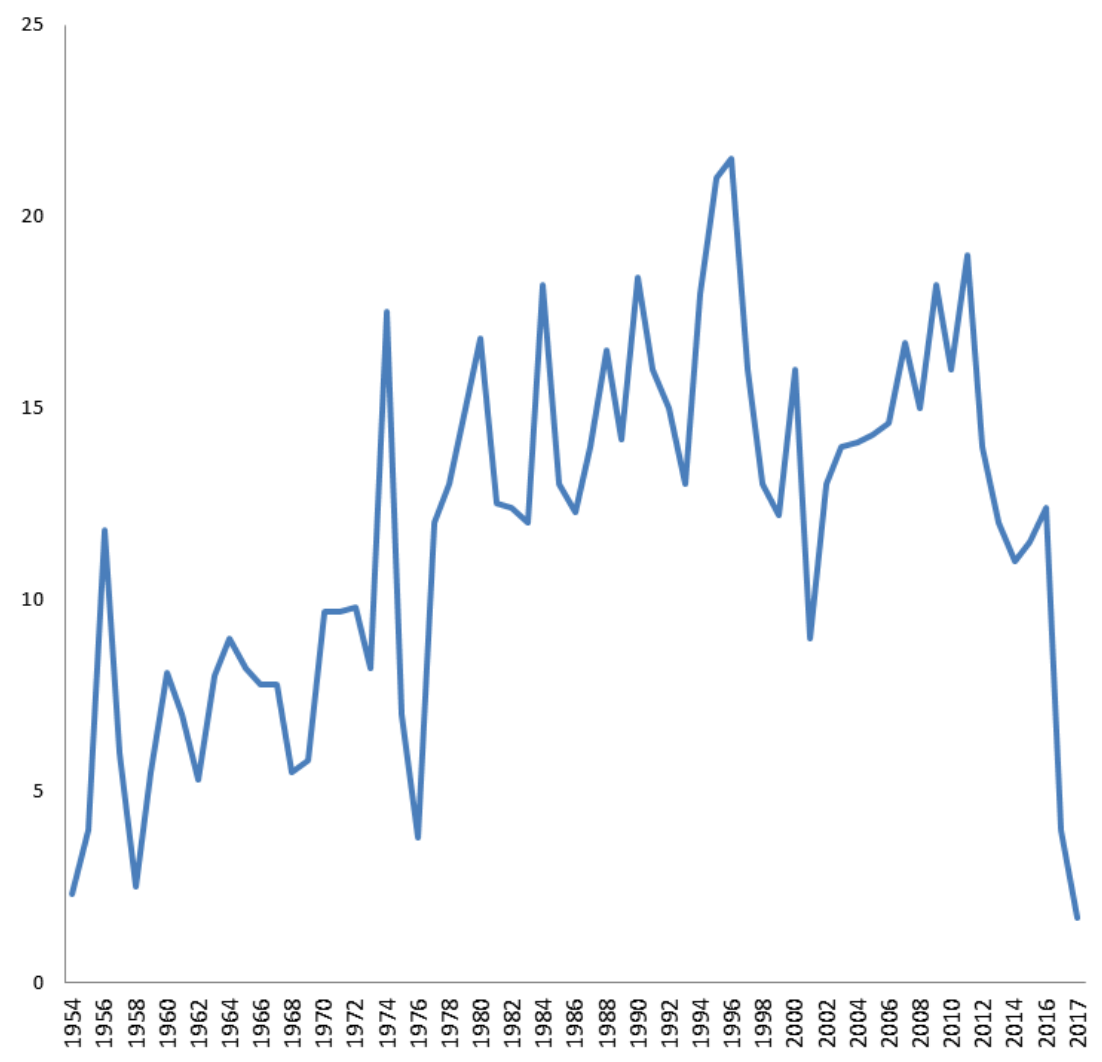

Figure 2. Growth in Average Currency with Public (\%, yoy).

Source: Economy Survey 2016-17

Note: Years are financial years and only even number yars have been labelled yoy: Year Over Year

After the announcement of demonetization by the Indian government, public was allowed to tender their old currencies at any office of the RBI or any bank branch and credit the value into their respective bank accounts till $30^{\text {th }}$ December 2016. [9] These old currencies would have to either reported by paying the applicable tax and penalties or would get extinguished. There are higher probabilities of a bulk proportion of this unaccounted money getting extinguished because the tax rate and consequent lawful concerns could be prohibitively high for such money. [10]

The demonetization of large denomination currency is perhaps not similar to the demonetization of black money. Some cash holdings were perfectly "white" as income has been declared and taxes on such net income has been paid and is not applicable in the first position for example agricultural income. Cash holdings arising from such income could easily be deposited into banks while black money would face various complicacies. Black money holders could declare their unaccounted assets and pay taxes at a penalty rate; continue to conceal it without exchanging their old currencies and thus suffering a tax rate of $100 \%$; or launder their black money, paying a price for converting the money into white. [3]

There is a background to the current decision of demonetization of 500 and 1000 rupee notes. Government of India, in the past, had adopted several steps to control unlawful menace, including creation of the Special
Investigative Team (SIT) in the 2014 budget; the Black Money and Imposition of Tax Act 2015; Benami Transactions Act 2016; the Information Exchange Agreement with Switzerland; Changes in the tax Treaties with Mauritius, Cyprus and Singapore; and the Income Disclosure Scheme. [3]

\section{Purpose of the Study}

The study primarily aims at-

(1) Studying the experience of the immediate impact of demonetization on Indian economy

(2) Examining the future impact of demonetization on Indian economy

\section{Materials and Method}

The present study is exploratory in nature. Keeping in view the nature of research, the methodology framed out here is essentially based upon the secondary information. The sources of data comprise of facts released by the Reserve Bank of India, journals, periodicals, web database, reports, regulatory publications and related planning documents. The primary information seems to be petite and hence the authors initiated the project with a review of selected literatures obtainable at disposal. 


\section{Observation and Discussion}

\subsection{Immediate Impact of Demonetization on Indian Economy}

\subsubsection{Severe Tightening in Money Supply}

India's inclination for hard cash is high and persistent. Indian consumers prefer it for a variety of reasons such as it is convenient, accepted everywhere, easy avoidance of taxes etc. With the elimination of $86 \%$ of the currency in circulation, a severe tightening in the economy had been observed. India is a cash-intensive economy. The cash accounts for over $80 \%$ of the transactions, which is almost two-thirds of the value of all transactions. [1] The public has experienced major problems for a few days owing to the dearth of currency in the economy. People who earned in hard currency and spent in cash and also who earned in noncash, but require to draw back in cash for consumption purposes has been affected. Many poor daily wage workers were left with no jobs and their daily income has stopped because employers are unable to pay their daily earnings. Consumption items which had a large element of cash involvement have seen a lower demand. [11] India has a very high proportion of consumer transactions carried out in cash compared with other countries. Figure 3 reveals the Persistence of Cash in Consumer Transactions in different countries. The figure shows that in Inida cash accounts for $98 \%$ of total transactions by volume and $68 \%$ of total transactions by value. [19]

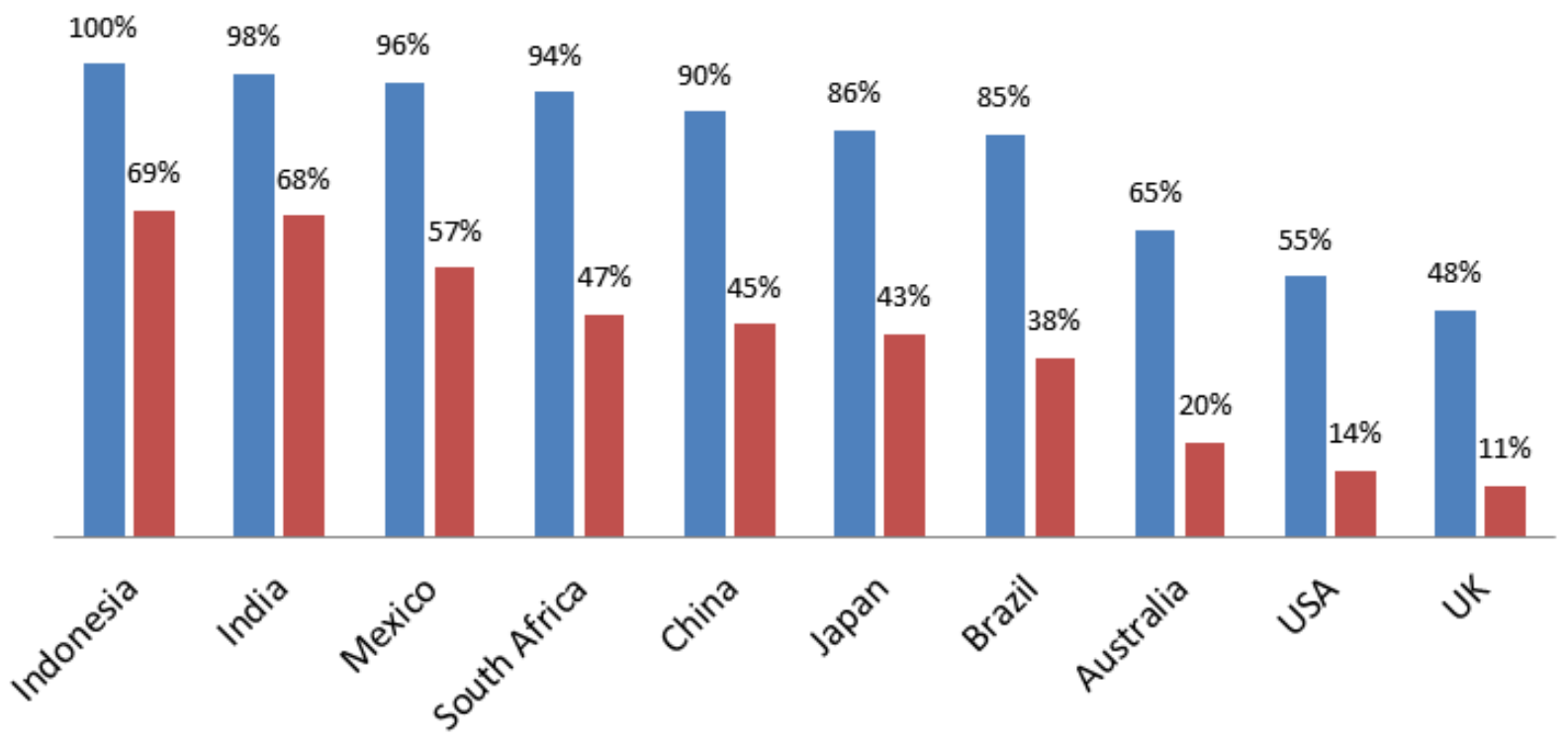

- Cash as \% of Volume of Consumer Payments - Cash as \% of Value of Consumer Payments

Source: PricewaterhouseCoopers 2015

Figure 3. The Persistence of Cash in Consumer Transactions.

\subsubsection{Rise in Credit Dealings}

In the light of liquidity crisis, traders in the economy have taken recourse to credit with the expectation that when the liquidity status is under control, the payments could be realized. In such situation, the prices of commodities have escalated instead of plummeted. The farmers and labourers have suffered the most as they have been used to get and save in currency notes. Electronic or transactions by the bank was limited to below $20 \%$ of daily transactions. Even farmers faced a temporary shortage of cash in hand that lead to a hold-up in payment. This scenario in the agriculture sector has affected the related sectors in the short term. As liquidity injects and cashless transaction gain acceptance, there would be growth in the system. [1]

\subsubsection{Move to Electronic Currency}

Referable to the cash crunch after demoneization, the entire economic system has been constituted to come to a dead end. With limitations on cash transactions, alternative patterns of payment like usage of plastic money (debit and credit cards), e-wallets and apps, online transactions using ebanking, etc. have a surge in demand. [12]

\subsubsection{Compression in Demand for Non-essentials Commodities}

Owing to the scarcity of money in the system, there was a fall in the demand for non-essentials commodities. However, the demand from segments which have access to a digital medium of exchange remained unaffected. [11]

\subsubsection{Slow-Down in Unorganized Retail Sector}

In the immediate term, the reduced ability of the unorganized sector to deal in cash has affected the demand. Unorganized retail sector like transport vehicles, fruits and vegetables and perishable items witnessed an adverse impact as they are supported by hard currency transactions. The slowdown in business eventually leads to excess supply over demand, which further lead to a fall in prices. [11] 


\subsubsection{Wallop on Real Estate}

People with black money and unaccounted incomes generally invest in real estate. It is noted that this segment has experienced a dip in the transactions. This has lead to a contraction in the investment rate in the building sector. [1] [14]

\subsubsection{Fall in Gold Market}

With the ban on high denomination currency, the gold market has seen a precipitous descent. The demand for gold has gone down and is not likely to rise in the near future. There has not been a radical rise in the gold prices as well. [7]

\subsubsection{Increase in Tax Collection}

In an attempt to get rid of unaccounted earnings, individuals have purchased goods and services and paid property taxes. This has brought a spurt in the indirect taxes in addition to property tax collections. Therefore, there has been a higher tax net and a better tax to GDP ratio. [12]

\subsubsection{Political Parties in Crisis Ahead of Polls}

Demonetization has taken aback political parties as state election 2017 is approaching in nearly five states. In large states, cash donations are a huge part of "election management". In such situation of monetary crisis, big political parties would have to completely restraint campaign approaches. [13]

\subsubsection{Impact on Agriculture Sector}

As per Credit Rating Information Services of India Limited (CRISIL) report, agricultural sector in India was expected to grow at $4 \%$ in the current year, but on account of demonetization this forecast proved to be wrong. Farmers are running out of cash to buy seeds, fertilizer, equipments, and even payment of wages to workers and commission to agents, etc. RBI report reveals that $78 \%$ of the population lacks knowledge of the internet in which almost $80 \%$ to $85 \%$ are farmers. Farmers are uneducated and unaware about internet banking system. Moreover, the banking system in most of the villages is not yet developed and so villagers need to go to the cities to avail the banking facilities. Thus, Farmers spent most of the time in exchanging the old notes in banks. [14]

\subsection{Future Impact of Demonetization on Indian Economy}

\subsubsection{Improvement in Asset Quality of Banks and Softening of Bank Lending Rates}

Demonetization is likely to bring an alteration in the saving practices of the Indians. There could be increased confidence of saving money in the banks rather than hoarding at home and use organized banking process for their spending requirements. Channelling cash through the banking sector would improve the medium to long term Current Account and Savings Account (CASA) ratio of the banks. With a majority amount of the money being brought within the horizon of the formal banking system by way of deposits, the banking sector is likely to be loaded with funds and this would help banks cut lending rates in the future. [1] [11]

\subsubsection{Spending Behaviour and Substitutes for Cash}

The demonetization indicates a possibility of transformation in spending behaviour on account of switching to other mode of transactions other than cash. There are numerous substitutes for cash in the contemporary financial system ranging from cheques, debit cards, credit cards, pre-paid cards, and mobile wallets. With frequent use of modern means of transactions, the consumption levels are expected to increase. This would boost spending on nonessentials commodities. In the long-run, it is expected to alter the lifestyles of the people. At the same time, it is essential to manage funds suitably. Mismanagement of funds would lead to consumer debt with a lower saving and would adversely affect the investment within the economy. [11]

\subsubsection{Uplift the Growth of Economy}

The extinguishing of the major share of the unaccounted legal tender would decrease from the liabilities of the government and would incorporate into its formal financial system. This would conclude that the government would get the money to spend without borrowing from the market. This would further connote that while interest rates would be less, the government expenditure on infrastructure projects would raise. Thus, in the process, would uplift the growth of the economy in the future. [3]

\subsubsection{Shrink the Demand for Real Estate}

The demonetization move is expected to have far reaching effects on real estate. Black money is responsible for the sharp escalation in prices of properties which would now see a drastic fall. It has been experienced in the rural areas that fertile lands are being bought, not for agriculture, but for real estate deals and to switch the black money into white money. The demonetization and following reduction in black economy would shrink the demand for such lands. Demonetization would dampen cash transactions in real estate. [1]

\subsubsection{Tackle Terror Funding}

Counterfeit currency has been a main setback of India and is often tied to terror or insurgency funding. According to a study by the Indian Statistical Institute in 2016, the amount of fake currency in circulation is about $0.02 \%$ of the total value of currency which is an insignificant part. Nevertheless, the point to which this counterfeit money bothers lives of ordinary people requires attention and compels the government to spend exhaustively on security and anti-terror activities. Demonetization move would tackle counterfeit notes that terrorists use to have mayhem in the nation. [15] Fake Indian Currency Notes (FICN) system would be taken down by the demonetization measures. Withdrawal of 500 and 1000 rupee notes out of circulation would affect the associations producing FICN's, thus affecting the financial support to terrorist. This move would further curtail the financial support for anti-social elements like smuggling, espionage etc. [1] 


\subsubsection{Addressing the Problem of Corruption and the Black Economy}

It is expected to eliminate the black money from the economy as they will be blocked considering the holders will not be in a position to deposit the same in the banks. Since hoarders would either have to pay punitive taxes (and probably be subject to further investigation), or have to turn their cash to scrap, the economy would get rid of significant amounts of black money. By the end of December 2016, about $80 \%$ of the high denomination currency notes made it back to the banks. The attempt will further be successful to fetch substantial amounts of cash to the banking system. [15]

\subsubsection{Formalization of the Economy}

The government's demonetization drive will have a positive impact on the economy in the long term as more people will move towards a formal economic system. The capital which was invested in unorganized sector would now be invested through financial institutions. This would lead to increase in the efficiency of transactions as India move towards digitized transactions. Moreover, formalization of the economic system coupled with Goods and Service Tax (GST) legislation, India would certainly experience boost in the economic system. [11] [16]

\subsubsection{Elevate the Tax to GDP Ratio}

This initiative of the government is likely to result in better tax compliance and elevate the tax to GDP ratio. Thus, demonetization would shrink borrowing and focus on improved fiscal management. Elevated tax to GDP ratio would give scope to the government to reduce the income tax rates, which would raise the disposable income with individuals and would improve consumption demand in the long term. [10]

\section{Conclusion and Inferences}

Government recent decision to dominate the higher value currency is one of the major steps towards the eradication of black money, control corruption, terror financing, and eliminate counterfeit currency in India. The announcement of the demonization of the currency has caused enormous hassle to the public. They were running several times to the banks to exchange, deposit or withdraw notes. The economy of the country has experienced a recession in the last few months, but it is expected to get back to its shape in the long run. The demonetization drive has affected some extent to the general public, but for the larger interest of the country such decisions are inevitable. Economic experts are busy analyzing the merits and demerit of this demonetization policy. However, there are only advantages of the policy and that will be reflected in the long term. Even though there is agony among the masses right at the moment, but the forecast is that its benefits would be witnessed in the long run. Former Prime Minister Manmohan Singh, who is a noted economist, former RBI governor and former Finance Minister of the country, refers the initiation as an 'organized looting and legalized plunder'. [17] Nevertheless, if merits are compared against demerits, it would be safe to conclude that the former outweighs the latter.

Ayhan Kose, Director of Development Prospects Group at the World Bank disclosed that the unfavourable effects of demonetization in India will disappear in the long term as any reform has short-term costs. It is further added that the World Bank is expecting growth over the financial year 2018 and 2019 supported by private consumption, infrastructure spending, and a rebound in investment growth. India has already undertaken a wide range of reforms. These reforms would loosen domestic supply bottlenecks and increased productivity, moderate inflation and civil service pay raise should go along to support real incomes and expenditure. [1]

\section{References}

[1] S. Balamurugan and B. K. Hemalatha, "Impacts on Demonetization: Organized and Unorganized Sector", IOSR Journal of Humanities and Social Science, e-ISSN: 22790837, p-ISSN: 2279-0845, 2016, pp. 01-11.

[2] K. Veerakumar, "A Study on People Impact on Demonetization", International Journal of Interdisciplinary Research in Arts and Humanities, vol 2, issue 1, 2017, pp. 9-12.

[3] Economic Survey 2016-17, "Demonetisation: To Deify or Demonize?", Economic Division, Department of Economic Affairs, Ministry of Finance, Government of India, January, 2017, pp. 53-81.

[4] "Withdrawal of Legal Tender Status for INR 500 and INR 1000 Notes: RBI Notice (Revised)". Reserve Bank of India, 8 November 2016.

[5] "Demonetisation: 5 Countries that tried Currency Reforms and Failed", http://www.business-standard.com/article/economypolicy/demonetisation-5-times-countries-tried-currencyreforms-and-failed-116111 800271_1.html, November 18, 2016.

[6] "The Biggest Demonetization Failures in the World", http:/www.speller step.com/latest/biggest-demonetiztio nfailures-world, December 20, 2016.

[7] S. N. Ahamad, G. Shaikshavali, Y. Reshma andV. Sumalatha, "Demonetization: The Effect on Indian Economy", Interntional Journal of Science Technology and Management, vol. 6, issue 01, January 2017, pp. 1008-1014.

[8] R. P. Deodhar, "Black Money and Demonetisation", November 14, 2016, SSRN: https://ssrn.com/ abstract= 2869172.

[9] "Notes out of circulation", The Times of India, 8 November 2016.

[10] "Demonetization and its impact", Event Update, HDFC Bank Investment Advisory Group, November 11, 2016.

[11] "Impact of demonetisation", 15 $5^{\text {th }}$ November, 2016, www.chase-india.com/Impact_of_demonetisation.pdf.

[12] Tax Research Team, "Demonetisation: Impact on the Economy" No. 182, 14-Nov-2016, National Institute of Public Finance and Policy, New Delhi.

[13] H. Singh, "Demonetization: Impacts on Indian Economy", International Journal of Business Management and Scientific Research, vol. 26, February, 2017, pp. 45-54. 
[14] CMA Jai Bansal, "Impact of Demonetization on Indian Economy", International Journal of Science Technology and Management, vol. 6, issue. 1, January 2017, pp. 598-605.

[15] A. Chanda, "Notes (and anecdotes) on Demonetisation", December 17, 2016, pp. 1-11,

https://sites01.lsu.edu/faculty/achanda/wp-content/uploads /sites/136/2016/12/Notes-on-Demonetization.pdf.

[16] "Economic Consequences of Demonetization of 500 and 1000 Rupee Notes", Economics: Policy View, Economics Division of Credit Analysis \&Research Limited [CARE Ratings], November 09, 2016.
[17] http://www.business-

standard.com/article/politics/demonetisation-an-organisedloot-and-legalised-plunder-says-manmohan-singh116112400334 1.html.

[18] Why Rs 500, Rs 1,000 notes' circulation surged in over 2 years, http://www.firstpost.com/india/chart-rs-500-rs-1000notes-form-86-of-total-value-of-currency-in-circulation3096964.html, Published Date: Nov 09, 2016.

[19] Disrupting cash: Accelerating electronic payments in India, PricewaterhouseCoopers Private Limited (PwCPL), October, 2015. 